\title{
The Risk for Boys from Poor Communities to Drop out from School: The Case of Khartoum, Sudan
}

Nagwa Babiker Abdalla Yousif ${ }^{\dagger *}$ and Shadia Abdel Rahim Mohammed ${ }^{¥}$

\section{Abstract}

In the current world, poverty and education are interconnected. Low level of education is the cause of poverty, as extreme forms of poverty do not allow many children to get a good education. This study investigates the risk factors that significantly increase the likelihood of pupils dropping out of school in Khartoum, Sudan. To accomplish the research, two factors are selected, namely absenteeism and low performance of pupils from poor, disadvantaged communities. A comprehensive interviewing is used to collect the necessary primary data along with the Multidimensional Poverty Index (MPI) data. The life of pupils is characterised by multi-dimensional poverty apace with illiteracy, displacement and large family size, parents' engagement in low paid jobs. The pupils presented multiple reasons (related to poverty) for their absenteeism and low performance. The results indicate that pupils are not clear with their future perspectives whether to drop out of the school or to continue their studies. The study concludes that poverty is the main reason for absenteeism and low performance that increases the likelihood of pupils dropping out of school.

Keywords: School Education; Poor Communities; Absenteeism; Migration; Performance; Sudan

\footnotetext{
${ }^{\dagger}$ Assistant Professor, College of Humanities and Sciences, Department of Sociology, Ajman University, Ajman, United Arab Emirates

* Corresponding Author, Email: nagwayousif78@gmail.com; nagwabfatima@gmail.com ₹Professor, School of Rural Extension Education and Development, Ahfad University for women, Omdurman, Sudan. (C) 2020 Yousif \& Mohammed. This is an Open Access article distributed under the terms of the Creative Commons Attribution License (http://creativecommons.org/licenses/by/2.0), which permits unrestricted use, distribution, and reproduction in any medium, provided the original work is properly cited.
} 


\section{Introduction}

The issue of poverty is widely discussed in the literature, but it will be counter-hegemonic and innovative to study poverty as a multidimensional phenomenon. The multidimensional measurement expands the scope of poverty analysis and constitutes an advanced and alternative way of measuring and explaining poverty (Alkire et al., 2017; Fahel \& Teles, 2018). The mixed picture of progress can be seen through the lens of the Global Multidimensional Poverty Index, produced by the United Nations Development Programme and the Oxford Poverty and Human Development Initiative. Today, 1.3 billion people in developing countries are multidimensionally poor (Alkire et al., 2017; Human Development Report, 2019).

In 2010, the United Nations replaced HPI with the Multidimensional Poverty Index (MPI). MPI, which is grounded in the capability approach, identifies overlapping deprivations at the household level in health, knowledge and standard of living, and shows the average number of poor people and deprivations with which poor households contend. The MPI dimensions are reflected in ten indicators: nutrition, child mortality (health), years of schooling, school attendance (education), cooking fuel, toilet, water, electricity, floor, assets (living standards). People are considered to be multidimensionally poor if they are deprived in at least 33\% of the mentioned indicators (Alkire et al., 2017; Michalowski, 2016).

Poverty is a high-risk factor for many children in underdeveloped countries to drop out of school. About 262 million children and youth of the developing countries were out of school in 2017- 64 million of primary school age, 61 million of lower secondary school age and 138 million of upper secondary age (UNESCO, 2019). The central purpose of this study is to probe the risk factors for boys from poor communities of Khartoum, Sudan dropping out from school.

Sudan is located in Sub-Saharan Africa. Indeed, Sub-Saharan Africa has the highest rates of exclusion. Besides, mere school attendance does not guarantee that children are learning. Over half the world's children cannot read and understand a simple text by the age of 10 (World Bank, 2019). For each country, household wealth is consistently the strongest predictor of school attendance (Roby et al., 2016).

Recently, primary education has been a priority amongst governments, mainly due to its perceived role in reducing poverty. With that, governments often lack sufficient resources to provide school education of acceptable quality (Kadzamira \& Rose, 2003). There is rapid urban expansion and poverty in Khartoum as a result of the overwhelming influx of migrants, the squalor and expansion of squatter areas around Khartoum (Abusin, 2005). The Khartoum State of Sudan has the highest enrolment rate for primary education compared to other states (UNICEF, 2014; Ministry of Education, 2013). Khartoum is also the state where multidimensional poverty is the least for the children group, in terms of prevalence and breadth of multi-dimensional poverty (Ballon \& Duclos, 2016).

Scholars argue that poverty is both a cause and an effect of insufficient access to or incomplete education (Roy et al., 2015; Hungi et al., 2018). Children of low-income families are less likely to enrol in and complete schooling because of the associated costs of attending schools, even when the education is provided free (Başer \& Karaman, 2015; Datzberger, 2018). The cost of uniforms, supplies and transportation may be beyond the means of a low-income family, especially when the family has several children of school age (Daoud, 2013).

Besides, civil unrest and employment instability also cause families to migrate (Bhattacharyya \& Vauquline, 2013; Manna, 2018; Maralov \& Sitarov, 2019). These factors make for high dropout rates among children (Chapman et al., 2011). Children that migrate with their parents are exposed to exploitation and also face several problems in terms of education, including poor psychosocial adaptation (Astashova et al., 2019; 
Bakker et al., 2009; Roy et al., 2015; Seregina et al., 2019; Tokareva et al., 2019).

Once children are enrolled in their year 1 , they have $82 \%$ chance of making it to the year $8^{\text {th }}$ academic year, with variations ranging from $65 \%$ for children in the poorest quintile to $94 \%$ in the wealthiest (Abusin, 2004; Sudan Household Health Survey (SHHS), 2010). Similarly, analysis of population census data indicates that school attendance peaks at age 11 and then drops during the following 10 years, in particular. Many pieces of research have been conducted to study the risk factors for school expulsion. There is no single risk factor that can be accurately used to predict who is at risk of dropping out. The accuracy of drop-out predictions increases when combinations of multiple risk factors are considered. Hence, this study identifies two risk factors or conditions that significantly increase the likelihood of pupils dropping out of school, namely absenteeism and low performance of pupils from disadvantaged communities. Against these backdrops, the research objectives are as follows:

- tracing boys at risk to drop out based on their irregular attendance and low performance;

- analysing the reasons and effects of irregular attendance;

- analysing the reasons and effects of low performance.

The article begins with an overview of the theory of multi-dimensional poverty. A section is included in which literature on the relationship between poverty and students' performance is described, especially with respect to primary school children from disadvantaged communities. After that, it discusses the methods deployed for this study. The final sections cover the results of the analysis, critical interpretations of the results and their potential implications to primary education policy and practices in disadvantaged communities.

\section{Methods}

\section{Study Area}

The study has been conducted on Umbanda Locality with considerable numbers of migrants and displaced people from the peripheral areas of Sudan.

\section{Research Sample and Data Analysis}

Four primary schools have been selected with the help of local authority to trace pupils at risks of leaving schools. A sample of 120 boys (from classes 3, 4, 5, 6 and 7) have been purposively selected from four schools. Data have been collected through structured interviews with pupils with the help of questionnaires.

Ethical issues have been resolved in light of the fact that the results of the study will be used for academic purposes. Permission to conduct the survey was obtained from the local authorities. It was ethically difficult to interview boys, who had dropped out of school because of poverty.

In recent years the idea of multi-dimensional poverty has received great attention of the researchers and policymakers across the globe (Bagli \& Tewari, 2019). The global Multidimensional Poverty Index (MPI) was also used for comparative analysis. The global MPI is an index of acute multi-dimensional poverty that covers over 100 countries. It is calculated using data from the most recent Demographic and Health Surveys (DHS), Multiple Indicator Cluster Surveys (MICS), Pan Arab Project for Family Health (PAPFAM) and national surveys (Global MPI Country Briefing, 2019: Sudan).

\section{Characteristics of Survey Respondents}

The age of studied pupils is higher compared to the normal age of primary school pupils engaged in the 8-year compulsory and free programme provided for children of 6-13 years old. Besides, almost $33 \%$ of pupils are more than 15 years old while still being in fourth and fifth years of study. $90 \%$ of pupils live with their migrant families that have migrated from rural areas and settled in Umbanda locality. The life of pupils is characterised by poverty, illiteracy and large family size as well as their parents' illiteracy and engagement in low-paid jobs. $52 \%$ of the pupils 
have around 9-12 family members, and $22.7 \%$ of pupils have a family size of more than 12 persons. In addition, near $79 \%$ of interviewed pupils are engaged in low-paid jobs and work during their study, almost $79 \%$ - work in the afternoon (see Table 1). The results are critically discussed in the following sections.

Table 1: Distribution of Respondents According to Socio-economic and Demographic Characteristics

Socio-economic characteristics

Age group (10-11)

Age group (12-13)

Age group (13-14)

Age group (Over 15)

Total

Year of study $\left(3^{\text {rd }}\right)$

Year of study $\left(4^{\text {th }}\right)$

Year of study $\left(5^{\text {th }}\right)$

Year of study $\left(6^{\text {th }}\right)$

Year of study $\left(7^{\text {th }}\right)$

Total

Live with (Family )

Live with (Friends)

Live with (Relatives)

Total

Place of origin (Khartoum)

Migrated from Rural Area

Total

Occupation of Father (Construction)

Occupation of Father (Food vendor)

Occupation of Father (Not working)

Total

Mother's occupation (Tea sale)

Mother's occupation (Food sale)

Housekeeping

Total

Head of the family (The father )

The mother

Brother

Total

Size of family (5-8)

Size of family (9-12)

Size of family (More than 12)

Total

Pupils engaged in work (Yes)

Pupils engaged in work (No)

Total

Types of work (Selling clothes)

Water vending

Cleaning

Total

Time spent at work (Afternoon)

Time spent at work (In the morning)

Holidays

Total

\begin{tabular}{|c|c|}
\hline $\mathrm{F}$ & $\%$ \\
\hline 25 & 20.8 \\
\hline 26 & 21.7 \\
\hline 29 & 24.2 \\
\hline 40 & 33.3 \\
\hline 120 & 100.0 \\
\hline 18 & 15.0 \\
\hline 47 & 39.1 \\
\hline 23 & 19.2 \\
\hline 13 & 10.8 \\
\hline 20 & 21.7 \\
\hline 120 & 100.0 \\
\hline 109 & 90.8 \\
\hline 1 & 0.8 \\
\hline 10 & 8.3 \\
\hline 120 & 100.0 \\
\hline 20 & 16.7 \\
\hline 100 & 83.3 \\
\hline 120 & 100 \\
\hline 56 & 47.7 \\
\hline 44 & 36.7 \\
\hline 20 & 26 \\
\hline 120 & 100 \\
\hline 42 & 35 \\
\hline 48 & 40 \\
\hline 30 & 25 \\
\hline 120 & 100 \\
\hline 60 & 50 \\
\hline 44 & 36.7 \\
\hline 16 & 13.3 \\
\hline 120 & 100 \\
\hline 30 & 25 \\
\hline 63 & 52.5 \\
\hline 27 & 22.5 \\
\hline 120 & 100 \\
\hline 95 & 79.2 \\
\hline 25 & 20.8 \\
\hline 120 & 100 \\
\hline 40 & 42.1 \\
\hline 35 & 36.8 \\
\hline 25 & 21.1 \\
\hline 95 & 100 \\
\hline 75 & 79 \\
\hline 10 & 10.5 \\
\hline 10 & 10.5 \\
\hline 95 & 100 \\
\hline
\end{tabular}

Source: Elaborated by the Authors based on data from Field Work 2019 


\section{Results}

Comparative analysis of Human Development Report confirms the multi-dimensional nature of the causes of poverty and high risks for boys' dropping out from school (see Table 2). Besides, the research unravels that there remains a link between estimated gross national income per capita level and mean years of schooling. Table 3 unfolds that population with at least some secondary education in Sudan has the lowest percentage. Labour force participation rate in Sudan is very high among boys of 15 years of age and older. This means that many of them often drop out of schools because of financial of constraints and poverty. Table 4 paints the factors triggering multi-dimensional poverty in Sudan.

\begin{tabular}{|c|c|c|c|c|c|}
\hline & & Sudan & South Sudan & $\begin{array}{l}\text { Sub-Saharan } \\
\text { Africa }\end{array}$ & World \\
\hline HDI rank (2018) & & 168 & 186 & - & - \\
\hline \multirow[t]{2}{*}{ Gender Development Index } & Value & 0.837 & 0.839 & 0.891 & 0.941 \\
\hline & Group & 5 & 5 & - & - \\
\hline \multirow{2}{*}{$\begin{array}{l}\text { Human Development } \\
\text { Index (HDI), value } \\
\end{array}$} & Female & 0.457 & 0.369 & 0.507 & 0.707 \\
\hline & Male & 0.546 & 0.440 & 0.569 & 0.751 \\
\hline \multirow{2}{*}{$\begin{array}{l}\text { Life expectancy } \\
\text { at birth (years) }\end{array}$} & Female & 66.9 & 59.1 & 62.9 & 74.9 \\
\hline & Male & 63.3 & 56.1 & 59.4 & 70.4 \\
\hline \multirow{2}{*}{$\begin{array}{l}\text { Expected years } \\
\text { of schooling (years) }\end{array}$} & Female & 7.7 & 3.5 & 9.3 & 12.7 \\
\hline & Male & 8.3 & 5.9 & 10.4 & 12.6 \\
\hline \multirow{2}{*}{$\begin{array}{l}\text { Mean years } \\
\text { of schooling (years) }\end{array}$} & Female & 3.2 & 4.0 & 4.8 & 7.9 \\
\hline & Male & 4.2 & 5.3 & 6.6 & 9.0 \\
\hline \multirow{2}{*}{$\begin{array}{l}\text { Estimated gross national income per } \\
\text { capita (2011 PPP \$) }\end{array}$} & Female & 1.759 & 1.277 & 2.752 & 11.246 \\
\hline & Male & 6.168 & 1.633 & 4.133 & 20.167 \\
\hline
\end{tabular}

Source: Elaborated by the Authors based On data from the Human Development Report 2019, United Nations Development Programme (UNDP).

Table 3: Population with at Least Some Secondary Education and Labour Force Participation Rate

\begin{tabular}{l|l|l|l|l|l|}
\hline $\mathbf{2 0 1 0 - 2 0 1 8}$ & & Sudan & South Sudan & $\begin{array}{l}\text { Sub-Saharan } \\
\text { Africa }\end{array}$ & World \\
\hline $\begin{array}{l}\text { Population with at least some } \\
\text { secondary education (in \%, at the age } \\
\text { of } 25 \text { and older) }\end{array}$ & Female & 15.3 &.. & 28.8 & 62.8 \\
\cline { 2 - 7 } & Male & 19.6 &.. & 39.8 & 71.2 \\
\hline $\begin{array}{l}\text { Labour force participation rate (in \%, at } \\
\text { the age of } 15 \text { and older) }\end{array}$ & Female & 24.5 & 71.8 & 63.5 & 48.0 \\
\cline { 2 - 7 } & Male & 70.3 & 74.3 & 72.9 & 74.9
\end{tabular}

Source: Elaborated by the Authors Based on Data from Human Development Report 2019, United Nations Development Programme (UNDP).

In Sudan, the percentage points of the key factors contributing to multi-dimensional poverty are as follows: health- $21 \%$; education- 29\%; and standard of livingalmost $50 \%$. It is arguable that multi-dimensional poverty has triggered low performance and absenteeism among pupils in Sudan, the analysis of which are given below.

\section{Low Performance of the Pupils}

The following data were received. Nearly $79 \%$ of the pupils stated the deterioration in their grades in 5, 6 and 7 academic years. Besides, 
another $79 \%$ of the pupils stated the lack of time as the main reason for their low performance. $80 \%$ of the pupils stated that low attendance might also be a reason for low performance, while only $29 \%$ of the pupils indicated that

\begin{tabular}{|c|c|c|c|c|}
\hline & & Sudan & $\begin{array}{l}\text { South } \\
\text { Sudan }\end{array}$ & $\begin{array}{l}\text { Sub-Saharan } \\
\text { Africa }\end{array}$ \\
\hline \multirow{2}{*}{$\begin{array}{l}\text { Multi-dimensional Poverty Index } \\
\text { (2007-2018) }\end{array}$} & Year of survey & 2014 & 2010 & - \\
\hline & Value & 0.279 & 0.580 & 0.316 \\
\hline $\begin{array}{l}\text { Population vulnerable to multi- } \\
\text { dimensional poverty }\end{array}$ & $\ln \%$ & 17.7 & 6.3 & 17.2 \\
\hline $\begin{array}{l}\text { Population with income below } \\
\text { poverty line (2007-2018) }\end{array}$ & $\ln \%$ & 46.5 & 82.3 & 43.7 \\
\hline \multicolumn{5}{|l|}{ Multi-dimensional poverty factors } \\
\hline Health & $\ln \%$ & 21.1 & 14.0 & 22.2 \\
\hline Education & $\ln \%$ & 29.2 & 39.6 & 29.6 \\
\hline Standard of living & $\ln \%$ & 49.8 & 46.5 & 48.1 \\
\hline
\end{tabular}

Source: Elaborated by the Authors based on Data from Human Development Report 2019, the United Nations Development Programme (UNDP). Estimates modelled by the International Labour Organisation.

Table 5: Distribution of the Respondents According to the Characteristics and Effects of Low Performance

\begin{tabular}{|c|c|c|}
\hline Characteristics of low performance & Frequency & Percentage (\%) \\
\hline \multicolumn{3}{|l|}{ Frequency } \\
\hline Once & 14 & 14.6 \\
\hline Twice & 31 & 32.6 \\
\hline Thrice & 50 & 52.7 \\
\hline Total & 95 & 100 \\
\hline \multicolumn{3}{|l|}{ Grades } \\
\hline 5th & 5 & 10 \\
\hline 6 th & 11 & 22 \\
\hline 7th & 34 & 68 \\
\hline Total & 50 & 100 \\
\hline \multicolumn{3}{|l|}{$\begin{array}{l}\text { Reasons for low performance: } \\
\text { I do not have time to do homework }\end{array}$} \\
\hline Yes & 95 & 7 \\
\hline No & 25 & 9.1 \\
\hline Total & 120 & 20.9 \\
\hline The classroom is very crowded & & 100 \\
\hline Yes & 35 & 29.2 \\
\hline No & 85 & 70.8 \\
\hline Total & 120 & 100 \\
\hline I missed some lessons & & 80 \\
\hline Yes & 96 & \\
\hline No & 24 & 20 \\
\hline Total & 120 & 100 \\
\hline \multicolumn{3}{|c|}{ Do your parents encourage you to do your homework? } \\
\hline Yes & 10 & 8.3 \\
\hline No & 110 & 91.7 \\
\hline Total & 120 & \\
\hline
\end{tabular}

Source: Elaborated by the Authors Based on Data from Field Work, 2019 overcrowded classrooms might hinder the educational process. $92 \%$ of pupils noted that their parents had never encouraged them to study nor revised their homework. 


\section{Absenteeism}

There are $47 \%$ of pupils that remained absent for two days per week, about $37 \%$ were absent for three days, while $17 \%$ did not attend school for the whole week. For $79 \%$ of pupils, work is the main reason for absenteeism, about $83 \%$ noted that their families could not afford their transportation and food. Indifference, lack of motivation and hatred for schools were also among reasons indicated by pupils (Table 6). The results indicate that pupils were not clear with their future perspectives, only $8 \%$ of pupils have decided to continue their education, while $33 \%$ will leave schools and about $58 \%$ do not know what to do (Table 7).

\begin{tabular}{|c|c|c|}
\hline Absenteeism & Frequency & Percentage (\%) \\
\hline \multicolumn{3}{|c|}{$\begin{array}{l}\text { How often do you skip school per } \\
\text { week? }\end{array}$} \\
\hline Two days & 56 & 46.7 \\
\hline Three days & 44 & 36.7 \\
\hline Sometimes the whole week & 20 & 16.6 \\
\hline Total & 120 & 100 \\
\hline \multicolumn{3}{|l|}{ The reasons of absenteeism } \\
\hline \multicolumn{3}{|l|}{ Work } \\
\hline Yes & 95 & 79.1 \\
\hline No & 25 & 20.9 \\
\hline Total & 120 & 100 \\
\hline \multicolumn{3}{|c|}{ Family has no money for school } \\
\hline Yes & 100 & 83.3 \\
\hline No & 20 & 16.7 \\
\hline Total & 120 & 100 \\
\hline \multicolumn{3}{|l|}{ Indifference } \\
\hline Yes & 15 & 12.5 \\
\hline No & 105 & 87.5 \\
\hline Total & 120 & 100 \\
\hline \multicolumn{3}{|l|}{ Hatred for school } \\
\hline Yes & 86 & 71.7 \\
\hline No & 34 & 28.3 \\
\hline Total & 120 & 100 \\
\hline \multicolumn{3}{|l|}{ Lack of motivation } \\
\hline Yes & 74 & 61.7 \\
\hline No & 46 & 38.3 \\
\hline Total & 120 & 100 \\
\hline
\end{tabular}

The late enrolment of pupils in schools might be the factor that leads them to leave schools. The age of many schoolchildren in Sudan is not appropriate for their actual academic year, which is an additional risk factor for dropping out
(UNICEF, 2014). The study confirms the high poverty of pupils' families as one of the reasons to leave schools and find a source of income. SHHS (2010) has found that the low wealth status of the family negatively correlates with 
school exclusion, $52 \%$ of primary school-aged children are from among the poorest households compared to $4 \%$ from the richest ones. According to Colclough et al. (2000), the income of the father is linked to the continuity or discontinuity of child's school education; most drop-outs are connected to fathers' unemployment. Due to low income levels of the families, the majority of pupils work during study that leads to their absenteeism. According to labour force survey 2011, in Sudan almost 20\% of children aged 10-12 are found to be working, and among these children three quarters are often out of school (Guarcello et al., 2011).

One can note that child's labour creates pressure on child's time (Croft, 2002). For example, a child that combines work and school, depending on the nature and volume of work, can have irregular school attendance. Persistent absenteeism among pupils might lead to their drop-out from school (Filmer, 2008); the same goes for low achievements. Furthermore, this observation is mostly visible for pupils of classes 6 and 7.
Similarly, according to Sudan education survey 2008, the highest drop-out rate among boys is indicated in 6 and 7 academic years. The Sudan Household Health Survey (SHHS, 2010) has found that once children are enrolled in the first academic year, they have an $82 \%$ chance of making it to the 8th year, with variations ranging from $65 \%$ for children in the poorest quintile to $94 \%$ in the wealthiest. Links between low achievements and drop-out have been noted (low-performing children are at some stage more likely to drop out of school, then highperforming ones) (Cardoso \& Verner, 2007). A high percentage of boys have no interest in school, which may relate to low performance. According to the study of Rumberger \& Thomas (2000), pupils might lose interest in school due to the lack of encouragement on the part of their parents. Parents' illiteracy also contributes to absenteeism and low performance of pupils as their parents do not encourage or support their education. It is also evident that children whose parents have received some sort of schooling are more likely to attend school (UNICEF, 2014).

\begin{tabular}{l|l|l|}
\hline \multicolumn{3}{|l|}{ Table 7: Distribution of Respondents According to Future Perspectives } \\
\hline Future Perspective & Frequency & Percentage (\%) \\
\hline $\begin{array}{l}\text { Future plans } \\
\text { Continue education }\end{array}$ & 10 & 8.4 \\
Leave the school & 40 & 33.3 \\
I do not know & 70 & 58.3 \\
Total & 120 & 100 \\
\hline Reasons for leaving the school & & \\
Work (I need money) & 20 & 16.8 \\
I have to support my family & 10 & 8.4 \\
New skills & 10 & 58.3 \\
Total & 40 & 100 \\
\hline Source: Elaborated by the Authors Based on Data from Field Work 2019
\end{tabular}

\section{Discussion}

The authors have found that among Sudan's multi-dimensionally poor, there are more children and young people that reside in rural areas, though not necessarily working in agriculture. This observation bear resonance to the findings of Aguilar \& Sumner (2020).
In their study by Alkire et al. (2017), they found that children are more afflicted by poverty, both in terms of incidence and intensity than adults. Thirty-seven per cent of children are multidimensionally poor, compared to $21 \%$ of the adults. In all 103 analysed countries, the MPI among children is higher than the MPI among adults, and the difference between the two figures is statistically significant in 82 countries. 
In 19 out of 103 countries, representing $41 \%$ of the sample, the estimated headcount ratio for children is at least ten percentage points higher than the estimated headcount ratio for adults. The differences in the incidence of poverty are highest for Sudan, Djibouti and Laos (Alkire et al., 2017).

The assessment of multi-dimensional poverty in Sudan and South Sudan shows regional and subnational population differences in the unidimensional and multi-dimensional poverty status of people in both countries. Poverty in Sudan is generally less severe than in South Sudan, with a pattern showing (1) lesser unidimensional incidence of poverty, (2) lower multi-dimensional poverty indices and prevalence, but similar breadth, both for adults and children. This pattern is also visible in Khartoum, the study area and Western Equatoria. These are the states with the least poverty, when compared to Northern Darfur and Warap as the states with the greatest poverty, both for adults and children, in Sudan and South Sudan respectively. Policy intended at reducing poverty in each of the two countries should recognise the poverty differences across age groups, and geographical areas (Ballon \& Duclos, 2016).

Even though decent progress has been made in universalisation of primary education in the study area, as is evident from increased enrolment and higher literacy levels, the situation is still adverse in many areas characterised by wide gender gaps, large share of drop-outs and absenteeism among the schoolchildren. This finding is similar to the findings of Maji \& Sarkar (2017) in their case study on intra-district disparities in primary education in the Bankura district of West Bengal.

Speaking from a slightly different context, migration can provide temporary relief from poverty, but it does not give a permanent solution. It raises many questions like how the needs of the distressed migrants can be addressed and how the children of the migrants be integrated into the education system. There is an urgent need to introduce migrants' children to formal or non-formal educational systems encompassing their basic right to education. Of course, education and skills can help them to break the vicious cycle of poverty and lead a dignified and meaningful life (Roy et al., 2015).

Poverty in Sudan contributes to the suffering of millions of people. Its determinants do not differ significantly from the determinants of this phenomenon in other countries of Sub-Saharan Africa. Economic development and fight against poverty should be the priority for the authorities in Khartoum. Internal conflict resolution and national reconciliation are the key issues that should be the starting point towards eliminating poverty in the country (Michalowski, 2016).

\section{Conclusion}

The central aim of this study was to examine the risk factors for boys from poor communities of Khartoum, Sudan dropping out of school. The study has found the following risk factors of boys' school drop-out: low performance and persistent absenteeism. Moreover, it can be stated that drop-out from school can rarely be put down to one event or one impact. Drop-out is influenced by a range of interacting factors, which are specific to each child. Drop-out is seen as a process rather than an event. Finally, it can be concluded that poverty is a main contributor to child's absenteeism. Economic conditions often negatively impact low-income families that may rely on the labour of their children to contribute to the family income. Schools should pay attention to these risk factors (treat the problems of irregular attendance, low achievements and reduced interest in education). The roles that parents and schools need to play in curbing absenteeism are that of guiding and counselling the pupils, providing recreation centres, forming groups to sensitise parents to the importance of education and compliance with school requirements. Regulatory bodies should encourage schools to promote education, reduce the number of dropouts and motivate pupils to continue their studies. Public authorities should also increase the number of vocational training centres for those pupils who have lost their interest in school. 


\section{References}

Abusin, A. (2004). Governance in Khartoum State. United Nations Development

Programme/ Ministry of Finance - Support to Local Governance Project Khartoum State, Sudan.

Abusin, A. (2005). Understanding sustainable livelihood: Changing patterns in poor urban settlements in the Sudan. Khartoum: ITDG, Practical Action Research.

Alkire, S., Jindra, C., Robles, G. \& Vaz, A. (2017). Children's Multi-dimensional Poverty:

Disaggregating the global MPI. OPHI Briefing, 46, 1-17.

Astashova, N.A., Bondyreva, S.K. \& Zhuk, O.L. (2019). Resources of interactive educational space as a basis for the organisation of multicultural education. The Education and science journal, 21(3), 29-49. (In Russian). DOI: https://doi.org/10.17853/1994-5639-2019-329-49.

Bagli, S. \& Tewari, G. (2019). Multi-dimensional Poverty: An Exploratory Study in Purulia District, West Bengal, Economic Affairs, 64 (3), 517-527.

Bakker, C., Elings-Pels, M., \& Reis, M. (2009). The impact of migration on children in the Caribbean. Bridgetown, Barbados: UNICEF Office for Barbados and Eastern Caribbean.

Ballon, P., \& Duclos, J.-Y. (2016). A Comparative Analysis of Multi-dimensional Poverty in Sudan and South Sudan. African Development Review, 28(S2), 132-161.

Başer, Z., \& Karaman, A. C. (2015). Enacting the national curriculum in a rural elementary school: A qualitative study of a beginning language teacher's experiences. Illköğretim Online, 14(1). doi: 10.17051/io.2015.67314.

Bhattacharyya, R., \& Vauquline, P. (2013). A mirage or a rural life line? Analysing the impact of Mahatma Gandhi Rural Employment Guarantee Act on women beneficiaries of Assam. Journal Space and Culture, India, 1(1), 83-101. https://doi.org/10.20896/saci.v1i1.10. Cardoso, A.R., \& Verner, D. (2007). School dropout and push-out factors in Brazil: The role of early parenthood, child labor, and poverty. IZA
Discussion Paper, No 2515. Bonn: Institute for the Study of Labour (IZA).

Chapman, C., Laird, J., Ifill, N., \& KewalRamani, A. (2011). Trends in High School Dropout and Completion Rates in the United States: 19722009. Compendium Report. NCES 2012-006. National Center for Education Statistics.

Colclough, C., Rose, P. and Tembon, M. (2000). Gender inequalities in primary schooling: the roles of poverty and adverse cultural practice. International Journal of Educational Development, 20, 5-27. doi: 10.1016/S07380593(99)00046-2.

Croft, A. M. (2002). Pedagogy in School Context: An intercultural study of the quality of learning, teaching and teacher education in lower primary classes in Southern Malawi: doctoral dissertation. University of Sussex.

Daoud, S. A. M. (2013). A critical review of gender equality in Education: Reflecting on the issues among poor communities in Sudan. In Gendered Voices (pp. 63-76). Brill Sense. doi: 10.1007/9789462091375_006.

Datzberger, S. (2018). Why education is not helping the poor. Findings from Uganda. World Development, 110, 124-139. doi: 10.1016/j.worlddev.2018.05.022.

Fahel, M. \& Teles, L. R. (2018). Measuring multidimensional poverty in the state of Minas Gerais, Brazil: looking beyond income. Revista de Administração Pública [online]. 2018, vol.52, n.3, pp.386-416. https://doi.org/10.1590/00347612154852.

Filmer, D. (2008). Disability, poverty, and schooling in developing countries: results from 14 household surveys. The World Bank Economic Review, 22(1), 141-163. doi: 10.1093/wber/Ihm021.

Global MPI Country Briefing: Sudan (Arab States) (2019). Oxford Poverty and Human Development Initiative (OPHI). Oxford Department of International Development Queen Elizabeth House, University of Oxford. www.ophi.org.uk.

Guarcello, L., Lyon, S., \& Rosati, F. C. (2011). Labour Market in South Sudan. Understanding 
Children's Work Programme Working Paper, 1112.

Human Development Report (2019). Published for the United Nations Development Programme (UNDP).

Hungi, N., Njagi, J., Wekulo, P., \& Ngware, M. (2018). Effects of language of instruction on learning of literacy skills among pre-primary school children from low-income urban communities in Kenya. Early Childhood Education Journal, 46(2), 187-199. doi: 10.1007/s10643-017-0850-1.

Kadzamira, E., \& Rose, P. (2003). Can free primary education meet the needs of the poor? Evidence from Malawi. International journal of educational development, 23(5), 501-516. doi: 10.1016/S0738-0593(03)00026-9.

Maji, K. \& Sarkar, Dr. S. (2017). Intra-District Disparities in Primary Education: A Case Study of Bankura District, West Bengal. Space and Culture, India, 4:3, 77-92. DOI: http://dx.doi.org/10.20896/saci.v4i3.214. Manna, P. (2018). Measuring Functionality of the Low-cost Housing for the Urban Poor: Unheard Voices of Asansol City, West Bengal. Space and Culture, India, 6(1), 91-106. doi: 10.20896/saci.v6i1.288.

Maralov V.G. \& Sitarov V.A. (2019). Positions of non-violence and non-interference in students: Comparative analysis. The Education and science journal, 21(4), 115-138. (In Russian) DOI: https://doi.org/10.17853/1994-56392019-4-115-138.

Michalowski, T. (2016). Poverty in Sub-Saharan Africa: The case of Sudan, International Business and Global Economy, 35(1), 183-196. Ministry of Education (2013). Educational Statistics Yearbook. Ministry of Education: UAE Robles Aguilar, G., \& Sumner, A. (2020). Who are the world's poor? A new profile of global multi-dimensional poverty. World Development, 126, 1-15.

Roby, J. L., Erickson, L., \& Nagaishi, C. (2016). Education for children in sub-Saharan Africa:
Predictors impacting school attendance. Children and Youth Services Review, 64, 110116.

Roy, A. K., Singh, P., \& Roy, U. N. (2015). Impact of rural-urban labour migration on education of children: A case study of left behind and accompanied migrant children in India. Space and Culture, India, 2(4), 17-34. doi: 10.20896/saci.v2i4.74.

Rumberger R., \& Thomas S. (2000). The distribution of drop-out and turnover rates among urban and suburban high schools. Sociology of Education, 73, 39-67. doi: $10.2307 / 2673198$.

Seregina, T., Zubanova, S., Druzhinin, V., \& Shagivaleeva, G. (2019). The Role of Language in Intercultural Communication. Space and Culture, India, 7(3), 243-253, DOI: https://doi.org/10.20896/saci.v7i3.524 Sudan Household Health Survey (SHHS) (2010). Ministry of Health and Central Bureau of Statistics. Retrieved on 10/09/2019 from, https://reliefweb.int/report/sudan/sudanhousehold-and-health-survey-second-round2010-summary-report.

Tokareva, E. A., Malysheva, O. G., \& Smirnova, Y. V. (2019). Prospects of the liberal arts educational model in the national history study. Opcion, 35(Special Issue 20), 11-29.

UNESCO (2019). Meeting Commitments: Are Countries on Track To Achieve SDG4? Montreal. UNICEF (2014). All In School Sudan Country Report On Out-Of-School Children UNICEF Sudan.

World Bank, UNESCO (2019). Institute for Statistics Join Forces to Help Countries Measure Student Learning." Press Release, 4 July. World Bank, Washington, DC. Retrieved on 11 November 2019 from, www.worldbank.org/en/news/pressrelease/2019/07/03/world-bank-unescoinstitute-for-statistics-join-forces-to-helpcountries-measure-student-learning. 